\title{
Carbon and soil microbial respiration in soil from conventional, organic vineyards and comparison with an adjacent forest
}

\section{Carbono e respiração microbiana do solo em videira convencional, orgânica e em comparação com floresta adjacente}

\author{
Higo Forlan Amaral ${ }^{1 *}$; José Ozinaldo Alves Sena²; Diva Souza Andrade ${ }^{3}$; \\ Aleksandra Gomes Jácome ${ }^{4}$; Rafael Granzioli Caldas ${ }^{5}$
}

\begin{abstract}
This aim of this study was to examine the effects of vineyard management and spatial heterogeneity of soil on chemical and microbial variables in comparison with an adjacent forest fragment. In 2000, two field experiments with Vitis labrusca (L.) were set up on an Oxisol of North Paraná, Brazil. In 2004, soil samples were taken to evaluate the following factors: (i) conventional (CONV) and organic (ORG) vineyard management and (ii) spatial heterogeneity of soil, row or inter-rows cultivation and at different sampling depths $(0-10 \mathrm{~cm}$ and $10-20 \mathrm{~cm})$, in a split-plot arrangement fitted to a randomized complete block with six replicates. The forest adjacent fragment was considered as undisturbed agricultural (or control) area. Chemical attributes of the soil in the ORG vineyard were improved in comparison to the soil in the forest, at a depth of $0-10 \mathrm{~cm}$, with the exception of total carbon. To microbial carbon $\left(\mathrm{C}_{\text {mic }}\right)$ values the both factors (vineyard management and special soil heterogeneity) contributed to changes in the contents this microbiological soil attributes in the areas evaluated. While, the spatial heterogeneity of the soil was the main factor to changes in soil microbial basal respiration, with higher values in the CONV rows. Regardless of the depth, the lowest $\mathrm{qCO}_{2}$ values were observed in the soil from the ORG vineyard and the forest. The cluster analysis showed that, represented on the Axis-X, the CONV vineyards, ORG vineyards and forest clustered from the negative to the positive, progressively, indicating greater similarity between ORG and forest. Moreover, when the spatial heterogeneity of the soil was plotted on the Axis-Y, the $0-10 \mathrm{~cm}$ layer appeared in the positive portion, and the $10-20 \mathrm{~cm}$ layer appeared in the negative portion. In the short term, it appears that different vineyard management methods affected microbial variables and some similarity between ORG and forest soil.
\end{abstract}

Key words: Cluster analysis, microbial activity, Vitis labrusca (L.)

\section{Resumo}

O objetivo deste trabalho foi examinar os efeitos de diferentes manejos de videira e espacial heterogeneidade do solo através de variáveis químicas e microbiológicas do solo e também comparar

\footnotetext{
${ }^{1}$ Prof. Dr. em Microbiologia e Bioquímica do Solo, Centro Universitário Filadélfia, UNIFIL, Av. J. K. 1626, C P 196, CEP: 86020000, Londrina, PR. E-mail: higoamaral@yahoo.com.br

${ }^{2}$ Prof. Dr. em Fitotecnia, Universidade Estadual de Maringá, UEM, Av. Colombo 5790, CEP 87020-900, Jardim Universitário, Maringá, PR. E-mail: joasena@uem.br

${ }^{3}$ Pesquisadora, PhD., Instituto Agronômico do Paraná, IAPAR, Rodovia Celso Garcia Cid, km 375 CEP 86047-902, Três Marcos, C P 481, Londrina, PR.E-mail: diva@iapar.br

${ }^{4}$ Prof $^{a}$ Dr $^{\mathrm{a}}$ em Produção Vegetal, Instituto Federal do Pará, Conceição do Araguaia, IFPA, Av. Magalhães Barata, 2254, Centro, Conceição do Araguaia-PA. CEP: 68540-000. E-mail: agjusus2004@hotmail.com

${ }^{5}$ Eng $^{\mathrm{o}}$ Agr $^{\mathrm{o}}$, M.Sc em Fitotecnia, Av. Colombo 5790, CEP 87020-900, Jardim Universitário, Maringá, PR. E-mail: rafaelgranziolicaldas@pop.com.br

* Autor para correspondência
} 
com uma área de floresta adjacente. Em 2000, dois experimentos de campo com Vitis labrusca (L.) foram instalados em Latossolo no norte do estado do Paraná, Brasil. Em 2004, amostras de solo foram coletadas para avaliar os seguintes fatores: (i) manejo de videira convencional (CONV) e orgânico (ORG) e (ii) espacial heterogeneidade do solo, considerando linha e entrelinha de cultivo e diferentes profundidades $(0-10 \mathrm{~cm}$ e 10-20 cm), aplicando o delineamento em blocos casualizados em seis repetições. A área de floresta adjacente foi considerada como área sem perturbação agrícola (ou controle). Os atributos químicos em solo com videira ORG foram maiores em comparação com solo sob floresta, na profundidade de $0-10 \mathrm{~cm}$, com exceção do carbono total. Para os valores de carbono microbiano $\left(\mathrm{C}_{\text {mic }}\right)$ ambos os fatores (manejo de videira e heterogeneidade espacial do solo) contribuíram para as mudanças observadas. Enquanto, apenas a heterogeneidade espacial do solo foi o principal fator para as alterações na respiração basal do solo, com os maiores valores observados nas linhas do CONV. Independente da profundidade, os menores valores de $\mathrm{qCO}_{2}$ foram observados em solo de videira ORG e floresta. A análise de agrupamento demonstrou que no Eixo-X, os manejos de videira agruparam-se da região negativa para positive na seqüência: $\mathrm{CONV}$, seguido do $\mathrm{ORG}$ e floresta, com alta proximidade entre ORG e floresta. Por outro lado, quando a espacial heterogeneidade do solo, representada pelo Eixo-Y, a camada de $0-10 \mathrm{~cm}$ foi positiva e a camada de $10-20 \mathrm{~cm}$ na porção negativa. Em curto tempo, foi possível detectar diferenças entre os atributos microbiológicos do solo em diferentes manejos de videira, e indicar algumas similaridades com solo sem alterações agrícolas.

Palavras-chave: Atividade microbiana, análise de agrupamento, Vitis labrusca (L.)

\section{Introduction}

In the Southern region of Brazil, vineyards are cultivated in different types of soils and climate and have great social and economic importance (DAL BÓ, 1992; SAAB et al., 2002, PAGLIA, 2007). In Paraná State, viticulture is concentrated in the north and northwest regions, where there are widespread areas cultivated by small hand-labor family systems. Although these regions have traditionally cultivated fine table grapes since 1990, the production has also diversified into varieties used for juice and wine (KISHINO, 2007). The productivity of a vineyard makes family farms possible; however, medium- to long-term use of conventional agricultural practices and techniques can damage both the quality and productivity of these crops (SAAB et al., 2002, MOTA, 2005). Some studies have reported that the use of alternative techniques and practices for grape production alters the levels of soil quality and hence productivity and/or quality of production (ROMBALDI et al., 2004; WUTKE et al., 2005, AMARAL et al., 2011b). Thus, farmers can achieve high production with lower costs and less environmental impact by replacing conventional vineyard cultivation practices with agricultural practices, such as planting cover crops between the rows, no tillage, alternative control of pests and diseases, and increasing the amount of organic material on the soil surface (FARIA; SOARES; LEÃO, 2004; ROMBALDI et al., 2004; WUTKE et al., 2004; BALOTA et al., 2007).

Soil microorganisms are key components of biosphere equilibrium because they act directly to metabolize organic matter and nutrients. Interference due to cultivation and soil management techniques can cause physical, chemical and biological changes to the soil. In perennial plants crops, such as grape vines, alterations in soil microbes significantly affect the biological and biochemical activities within soil, including basal respiration and microbial biomass (SCHERER 2005; XAVIER et al., 2006; BALOTA et al., 2007; BOHM et al., 2011). Although some agricultural practices, such as liming, can improve rhizobial population density and diversity (ANDRADE; MURPHY; GILLER, 2002), other conventional cultivation practices can disrupt populations of microorganisms in the soil, increasing their activities, accelerating the degradation of organic matter, and decreasing soil nutrient content (BALOTA et al., 2007; MATSUOKA; MENDES; LOUREIRO, 2003; NOGUEIRA et al., 2006; SAMPAIO; SANTOS; ARAÚJO et al., 2011). 
Microbial biomass has been used as a parameter to measure the amounts of nutrients in microbial cells and thus provides information about the recycling of nutrients, especially in studies that evaluate soil quality. Microbial activity, as measured by soil basal respiration, correlates directly with the decomposition of organic matter and nutrient recycling by microorganisms and is thus a useful tool for comparing different agricultural management systems and agricultural practices (POWLSON; BROOKES, 1987; WARDLE; GHANI, 1995; ANDRADE; COLOZZI FILHO; GILLER, 2003; BALOTA et al., 2003; NDOUR et al., 2008; AMARAL et al., 2011b). However, studies evaluating the effect of organic vineyard cultivation practices on soil microbial communities are scarce. Therefore, the objective of this study was to examine changes in carbon content and microbial activity due to vineyard management and spatial heterogeneity (sampling position and depth) of soil in organic and conventional vineyards in comparison with an adjacent subtropical forest fragment.

\section{Material and Methods}

Characteristics of the experimental sites and sampling

Two experiments were carried out in different areas, implementing two different methods of vineyard cultivation, organic (ORG) and conventional (CONV) management. The vineyards were located at $23^{\circ} 25^{\prime} \mathrm{S} 51^{\circ} 57^{\circ} \mathrm{W}$ at $580 \mathrm{~m}$ above sea level, in the northwestern region of Paraná State, Brazil, and neither vineyard was irrigated. The soil (Oxisol) is classified as a Typic Haplorthox (Soil Survey Staff, 1999) with a sandy texture, containing $206 \mathrm{~g} \mathrm{~kg}^{-1}$ clay, $27 \mathrm{~g} \mathrm{~kg}^{-1}$ silt and $767 \mathrm{~g}$ $\mathrm{kg}^{-1}$ sand, with a soil particle density of $2.65 \mathrm{~g} \mathrm{~cm}^{-3}$. According to Köppen's classification, the climate is characterized as a humid subtropical climate (Cfa) with a minimum temperature of $18^{\circ} \mathrm{C}$ (mesothermal) and a maximum temperature of $22{ }^{\circ} \mathrm{C}$, indicating hot summers, infrequent frosts, and a trend for rainfall in the summer months with no definite dry season. The forest area was located between the two experimental areas, and its vegetation is classified as a semideciduous subtropical forest (2000 m long and $120 \mathrm{~m}$ wide). During the sampling period, the rainfall was $125 \mathrm{~mm}$, the minimum and maximum temperatures were $19{ }^{\circ} \mathrm{C}$ and $31{ }^{\circ} \mathrm{C}$, respectively, and the minimum and maximum relative humidities were $52 \%$ and $80 \%$, respectively.

In 2000, two field experiments were set up on of North Paraná, Brazil. Vitis labrusca (L.) grape plants of the American variety, which is suitable for juice production, were planted in a randomized block design with six replications. The seedlings were trained on vertical "espaldeira" driving systems to a height of $90 \mathrm{~cm}$. Each $16 \mathrm{~m}^{2}$ experimental plot consisted of four plants arranged in $2 \times 2 \mathrm{~m}$ spacing.

\section{Soil and crop management}

The CONV vineyard was treated with a desiccant herbicide and manually weeded every two months as described in Amaral et al. (2011b). The CONV vineyard was fertilized with NPK 5-20-20 according to the manufacturer's recommendations and based on chemical analysis of the soil (VAN RAIJ et al., 1997). Desiccant herbicides (Glyphosate ${ }^{\circledR}$ ) were used to control "spontaneous" plants, and other agrochemicals were applied to control plant pathogens depended on the climatic conditions during the four-year cultivation period.

In the ORG management experiment, green cover crops were used between the rows, alternating between pork-bean (Canavalia ensiformis and Crotalaria spectabilis) in the summer and black oats (Avena strigosa) in the winter as well as other spontaneous grasses; the other grasses were mowed after flowering and deposited in the soil. These periods were interspersed with fallow periods, when nothing was planted, and the weeds were managed through manual control. This system was supplemented with the addition of fermented animal 
manure (BETTIOL; TRATCH; GALVÃO, 1997). Ecological management of pests and diseases, with the maintenance and enhancement of a functional biodiversity of agroecosystems, was carried out, as described by Altieri (2002). Alternative means are used to control pests and diseases, including biofertilizers (as described by Bettiol, Tratch e Galvão (1997), pesticides (such as sulfocalcium mixtures) and other natural extracts, for instance, Nim (Azadirachta indica) oil (ABREU JUNIOR, 1998; BURG; MAYER, 2001; WARDLE, 1995) as well as other alternative biological control of pests and diseases (BRASIL, 1999).

\section{Sampling and statistical design}

Soil sampling was carried out in February 2004 to evaluate the following treatments: (i) vineyards under organic (ORG) and conventional (CONV) management and (ii) spatial heterogeneity of soil within and between rows and at different sampling depths $(0-10 \mathrm{~cm}$ and $10-20 \mathrm{~cm})$ in a split-plot arrangement fitted to a randomized complete block with six replicates. The adjacent forest area, which separated the two vineyard experiments, was sampled only as reference and used in the multivariate discriminant analysis.

\section{Soil chemical analysis}

Soil samples were collected at depths of 0-10 $\mathrm{cm}$, packed in plastic bags and temporarily stored in coolers until chemical analysis processing. The samples were dried in a ventilated oven, passed through a sieve ( $2 \mathrm{~mm}$ mesh) and analyzed according to procedures described by Pavan et al. (1992). The $\mathrm{pH}$ was determined in a $0.01 \mathrm{~mol} \mathrm{~L}^{-1}$ $\mathrm{CaCl}_{2}$ solution using the potential acidity $(\mathrm{H}+$ Al) for SMP (Shoemaker, Mc Lean and Pratt) and atomic absorption spectrometry. Phosphorus (P) and potassium $(\mathrm{K})$ were extracted using Melich-1 and quantified by colorimetry using molybdenum blue and flame photometry, respectively. Calcium $(\mathrm{Ca})$, and magnesium $(\mathrm{Mg})$ were extracted with 1 mol L-1 $\mathrm{KCl}$ and quantified by atomic absorption spectrophotometer. Carbon (C) was determined according to the Walkley and Black procedure. Chemical variables were measured only for soil characterization and not included in the statistical analysis.

\section{Soil microbiological analysis}

For microbiological analysis, the moisture content of the samples was standardized to $70 \%$, and the soil samples were then passed through a sieve ( $4 \mathrm{~mm}$ mesh) and stored at $8{ }^{\circ} \mathrm{C}$ until analysis. The microbial carbon content $\left(\mathrm{C}_{\text {mic }}\right)$ was measured using a fumigation-extraction method, modified from Vance, Brookes and Jenkinson (1987), using two $20 \mathrm{~g}$ sub-samples of soil (fumigated and nonfumigated sub-samples). The fumigation was carried out with chloroform (without alcohol) in a vacuum-sealed desiccator for $24 \mathrm{~h}$; the second sub-sample (non-fumigated) was desiccated for the same amount of time but with only deionized water. Then, $0.5 \mathrm{~mol} \mathrm{~L}^{-1} \mathrm{~K}_{2} \mathrm{SO}_{4}$ was used as an extractor, and the carbon was quantified using acid-potassium dichromate oxidation (NELSON; SOMMERS, 1982). The $\mathrm{C}_{\text {mic }}$ was calculated as the difference in $\mathrm{C}$ content between the fumigated and nonfumigated samples, using the correction factor (Kc $=0.33$ ) from Sparling and West (1988). The basal respiration $\left(\mathrm{CO}_{2}-\mathrm{C}\right)$ was determined by incubating $20 \mathrm{~g}$ of soil (in a sealed bottle) with an open bottle containing a $0.5 \mathrm{M}$ solution of $\mathrm{NaOH}$ at $28^{\circ} \mathrm{C}$. The $\mathrm{CO}_{2}$ generated by microbial metabolism was determined first by the $\mathrm{BaCl}_{2}$ precipitation pathway and subsequently measured by acid titration with $0.1 \mathrm{M} \mathrm{HCl}$; the $\mathrm{CO}_{2}-\mathrm{C}$ was calculated using the volume of titrated acid used (ANDERSON; DOMSCH, 1978). The metabolic quotient $\left(\mathrm{qCO}_{2}\right)$ was calculated as the ratio between the $\mathrm{C}-\mathrm{CO}_{2}$ and $\mathrm{C}_{\text {mic }}$ values (SPARLING, 1997). 


\section{Statistical Analysis}

For the microbiological data, a split-plot ANOVA was performed using the statistical software SAS for Windows v 9.1 (SAS, 1998), with vineyard experiments in a randomized design treatment (plot) as the management factor and soil spatial heterogeneity (within rows and between rows) as the subplot factor. If the treatment main effect was significant and interactions were non-significant, then mean separation was carried out using the Scott-Knott test $(\mathrm{p}<0.05)$. If the interaction between treatment and spatial heterogeneity (or sampling position) was significant, the Scott-Knott test ( $p$ $<0.05$ ) was applied to treatment means separately for each sampling depth (or each position). For the microbiological data, including all vineyard treatments and the adjacent native forest area, we used multivariate discriminant analysis to classify treatments based on a Euclidean coefficient (AMARAL et al., 2011a; RAMETTE, 2007). Multivariate analysis was performed using BioEstat v. 5.0 software (AYRES et al., 2007).

\section{Results and Discussion}

\section{Soil chemical characterization}

Both the CONV and the ORG vineyards maintained soil $\mathrm{pH}$ values from 5.29 to 5.38 and potential soil acidity $(\mathrm{H}+\mathrm{Al})$ from 2.53 to 2.80 , indicating that these chemical variables were maintained in the short term (four years after the vineyards were planted). On the other hand, these values were different from those observed in the native forest soil, which had a $\mathrm{pH}$ value of 3.44 and a potential acidity of 5.03. However, we observed increased levels of $\mathrm{P}$ in the ORG vineyard soil (52.35 $\mathrm{mg} \mathrm{dm}^{-3}$ soil) compared to CONV soil (22.14 $\mathrm{mg} \mathrm{dm}{ }^{-3}$ soil) and native forest soil (8.06 soil $\mathrm{mg} \mathrm{P}$ $\mathrm{dm}^{-3}$ ). The average soil carbon (C) content did not vary between the forest and the ORG and CONV vineyards, with values ranging from 14.37 to 18.62 $\mathrm{g} \mathrm{C} \mathrm{dm}^{-3}$. The forest soil presented the lowest values of $\mathrm{Ca}, \mathrm{Mg}$ and $\mathrm{K}$, and there were also differences between the ORG and CONV vineyards (Table 1).

The chemical characterization showed that Oxisol under native forest cover typically demonstrated lower acidity and fertility. However, the $\mathrm{C}$ contents were similar between both vineyards and forest soils, showing that in a short period of time after different vineyard management methods were applied, there was no reduction of this nutrient in the soil. The preparations, practices and agricultural techniques used in the different vineyards indicated that there was a relative increase of the macronutrients $\mathrm{Ca}, \mathrm{Mg}$ and $\mathrm{K}$ in the soil from the ORG vineyard. Oxisol soils are highly acidic soils with low base saturation. Soil formation factors, especially the source material, exert greater influence on the spatial dependence of soil chemical attributes, while fertilizer and lime induced less spatial dependence due to the homogenization when different management systems were used (CAVALCANTE et al., 2007).

Table 1. Soil chemical characteristics in organic (ORG) and conventional (CONV) vineyards [Vitis labrusca (L.)] and an adjacent forest area. Soil samples were taken from the 0-10 cm layer.

\begin{tabular}{lccccccc}
\hline Treatments & $\mathrm{pH}$ & $\mathrm{H}+\mathrm{Al}$ & $\begin{array}{c}\mathrm{P} \\
\mathrm{mg} \mathrm{dm} \mathrm{soil}{ }^{-3}\end{array}$ & $\begin{array}{c}\mathrm{C} \\
\mathrm{g} \mathrm{dm} \mathrm{soil}^{-3}\end{array}$ & $\begin{array}{c}\mathrm{Ca} \\
-------------\mathrm{cmol} \mathrm{dm} \mathrm{soil}^{-3}------------\end{array}$ \\
\hline ORG & $5.29 *(0.29)$ & $2.80(0.14)$ & $52.35(3.59)$ & $15.06(0.67)$ & $4.24(0.04)$ & $1.70(0.02)$ & $0.52(0.08)$ \\
CONV & $5.38(0.12)$ & $2.53(0.13)$ & $22.14(3.12)$ & $14.37(0.81)$ & $1.81(0.32)$ & $0.90(0.16)$ & $0.25(0.05)$ \\
Forest & $3.44(0.10)$ & $5.03(0.31)$ & $8.06(0.51)$ & $18.62(0.17)$ & $0.70(0.18)$ & $0.28(0.05)$ & $0.11(0.15)$ \\
\hline
\end{tabular}

(*) Means of six repetitions, standard deviation in brackets, $\mathrm{pH}$ by $\mathrm{CaCl}_{2} 0.01 \mathrm{~mol} \mathrm{~L}^{-1}$, $\mathrm{C}$ determined by Walkley and Black, $\mathrm{P}$ and $\mathrm{K}$ by Mehlich, exchangeable $\mathrm{Ca}, \mathrm{Mg}$ and $\mathrm{H}+\mathrm{Al}$ : by $1 \mathrm{~mol} \mathrm{~L}^{-1} \mathrm{KCl}$.

Source: Elaboration of the authors. 


\section{Soil microbial carbon and microbial activity}

The factors that contributed to major changes in microbial carbon $\left(\mathrm{C}_{\text {mic }}\right)$ were vineyard management methods and sampling depth. Independent of sampling depth, the spatial heterogeneity of the soil contributed to changes in microbial basal respiration, with higher values in the CONV rows. The management method and the sampling depth were factors that contributed to the increase in $\mathrm{C}_{\text {mic }}$ increasing in ORG vineyard soil and forest soil (Table 2).

Table 2. Microbial biomass carbon $\left(\mathrm{C}_{\mathrm{mic}}\right)$ and basal respiration (MBR) in Oxisol from organic $(\mathrm{ORG})$ and conventional (CONV) vineyards [Vitis labrusca (L.)] and an adjacent forest area. Data from forest soil were not included in the statistical analysis.

\begin{tabular}{|c|c|c|c|c|}
\hline \multirow{2}{*}{ Treatment } & \multicolumn{2}{|c|}{ - } & \multicolumn{2}{|c|}{ - $10-10 \mathrm{~cm}-\mathrm{c}-\mathrm{-}-\mathrm{-}-\mathrm{-}$} \\
\hline & Row & Inter-row & Row & Inter-row \\
\hline & -------------. & $\mathrm{C}_{\text {mic }}$ & -1)----------- & -------- \\
\hline ORG & $265.22^{\#} \mathrm{Aa}$ & $257.21 \mathrm{Aa}$ & $171.31 \mathrm{Aa}$ & $155.13 \mathrm{Aa}$ \\
\hline CONV & $88.32 \mathrm{Ba}$ & $71.51 \mathrm{Ba}$ & $46.79 \mathrm{Bb}$ & $62.79 \mathrm{Ba}$ \\
\hline Forest & \multicolumn{2}{|c|}{307.59} & \multicolumn{2}{|c|}{270.13} \\
\hline & & $-\mathrm{MBR}(\mu$ & g soil $\left.^{-1}\right)---$ & ----- \\
\hline ORG & $0.183 \mathrm{Bb}$ & $0.238 \mathrm{Aa}$ & $0.145 \mathrm{Bb}$ & $0.206 \mathrm{Aa}$ \\
\hline CONV & $0.252 \mathrm{Aa}$ & $0.193 \mathrm{Bb}$ & $0.185 \mathrm{Aa}$ & $0.189 \mathrm{Ba}$ \\
\hline Forest & \multicolumn{2}{|c|}{0.366} & \multicolumn{2}{|c|}{0.250} \\
\hline
\end{tabular}

(\#) denotes the mean of six repetitions. Values followed by the same upper case letter comparing vineyard management methods with sampling depth are not significantly different by the Scott-Knott test $(P<0.05)$. Values followed by the same lower case letter comparing spatial heterogeneity (row and inter-rows) within vineyard managements are not significantly different by the ScottKnott test $(P<0.05)$.

Source: Elaboration of the authors.

The $\mathrm{C}_{\text {mic }}$ values were reduced in the vineyard soil compared to the forest soil, independent of management method. In the short term, dynamic microorganism populations respond promptly to interference in agricultural practices. In soils managed organically, the practices of planting cover crops (legumes and grasses), aimed at protecting the soil, reduced the occurrence of weeds and increased the organic matter content. In some studies, increased levels of organic matter and other nutrients, such as $\mathrm{P}$ and $\mathrm{N}$, benefited the biological activity, as demonstrated by increased $\mathrm{C}_{\text {mic }}$ levels (MÄDER et al., 2002; FLIEBACH et al., 2007). The authors suggested that in the long term, such practices could affect soil quality by increasing the levels of $\mathrm{C}_{\text {mic }}$ and balancing microbial activity. Araújo et al. (2011) reported that soil in an organically managed agricultural system in the northeast region of Brazil presents higher microbial activity and biomass and lower bulk density than that in conventional farming systems.

In the ORG and CONV vineyards at soil depths of 10-20 cm, reduced amounts of $\mathrm{C}_{\text {mic }}$ were observed, similar to the forest soil, indicting a more natural microbial profile. Likewise, under Brazilian Cerrado conditions, the soil microbial variables were decreased in the deeper layers (MATSUOKA; MENDES; LOUREIRO, 2003). In a study comparing different combinations of crop rotations and fertilizers, Liu et al. (2007) demonstrated that $\mathrm{C}_{\text {mic }}$ was significantly increased in organic systems compared to conventional systems. In Oxisol in the Brazilian Cerrado, Matsuoka, Mendes e Loureiro (2003) have shown that both conventional and organic vineyard soil contain reduced amounts of 
microbial carbon in 15 to $30 \mathrm{~cm}$ deep layers. The microbial carbon that represents the most active and living part of the organic matter is more sensitive to agricultural interference, as indicated by changes in soil even before the organic matter levels are significantly altered (MATSUOKA; MENDES; LOUREIRO, 2003; ARAÚJO et al., 2011).

The microbial basal respiration (MBR) values have shown that depth and sampling position (soil spatial heterogeneity) were the most relevant factors for distinguishing the MBR activity. At both tested depths within the rows, the MBR values were higher in the CONV vineyard soil. On the other hand, higher MBR values were observed at the same depths between rows in the ORG vineyard (Table 2). Overall, CONV soil management tends to stimulate microbial activity by adding substrates for easy and rapid metabolism (SPARLING, 1997). The values of MBR in the forest soil decreased with increasing depth (Table 2). In the ORG vineyard, the incorporation of crop residues into the soil resulted in enhanced microbial activity due to greater root biomass, plant root stimulation and intermediate levels of organic matter.

The lowest $\mathrm{qCO}_{2}$ values were detected in the soil from the ORG vineyard, demonstrating that vineyard management had a greater influence on this microbial variable. The $\mathrm{qCO}_{2}$ values ranged from 0.68 to $0.92 \mathrm{mg} \mathrm{CO}_{2}-\mathrm{C} \mathrm{g}^{-1} \mathrm{~h}^{-1} \mathrm{C}_{\text {mic }}$ in the forest soil and from 0.92 to $1.18 \mathrm{mg} \mathrm{CO}_{2}-\mathrm{C} \mathrm{C}_{\text {mic }} \mathrm{h}^{-1} \mathrm{~g}^{-1}$ in the ORG soil, and the soil spatial heterogeneity had no effect on these values (Figure 1). These results were also observed in the CONV vineyard rows, which demonstrated the highest $\mathrm{qCO}_{2}$ values (Figure 1). There was a reduction in $\mathrm{qCO}_{2}$ values corresponding to $2 \%$ in the $0-10 \mathrm{~cm}$ layer and $44 \%$ in the 10-20 cm layer in the CONV soil (Figure 1).
The lowest $\mathrm{qCO}_{2}$ values were observed at depths of $0-10 \mathrm{~cm}$ in the ORG rows and at depths of $10-20 \mathrm{~cm}$ in the forest soil.

A corresponding increase in $\mathrm{C}_{\text {mic }}$ and $\mathrm{CO}_{2}$ values in the ORG vineyard soil explains the reduced $\mathrm{qCO}_{2}$ values. The metabolic quotient $\left(\mathrm{qCO}_{2}\right)$ relates the level of the soil microbial basal respiration to the microbial carbon content (WARDLE; GHANI, 1995), demonstrating greater maintenance of $\mathrm{C}$ in the microbial cells in the ORG vineyard soil, and thus, higher $\mathrm{C}$ retention in the soil. Using cover crops between vineyard rows for perennial crops may enhance the humidity and temperature of the soil and, consequently, promote microbial growth (AMARAL et al., 2011b; SCHERER, 2005). In a vineyard, the use of cover crops in between rows may help maintain or restore soil fertility. The use of legumes and grasses as cover crops may also reduce the cost of production (BALOTA et al., 2007).

The high $\mathrm{qCO}_{2}$ values in the CONV vineyard indicated the greatest loss of $\mathrm{C}$ by MBR and low retention of carbon in microbial biomass, which are effects that are potentially attributable to soil changes or disturbances that reduce the microbial carbon. However, the microbial activity may also indicate changes in the microbial community in the four years since the vineyards were planted. In the conventional vineyard, the lack of cover crops between rows and the application of fertilizers with high water solubility could accelerate carbon recycling by increasing soil microbial activity (Table 2 and Figure 1). An alternative explanation for the increased $\mathrm{qCO}_{2}$ values in the CONV vineyard could be the chemical high solubility used for weed control, as Bohm et al. (2011) showed that microbial activity, as measured by MBR, was higher in soil




Figure 1. Soil metabolic quotient $\left(\mathrm{qCO}_{2}\right)$ in organic $(\mathrm{ORG})$ and conventional $(\mathrm{CONV})$ vineyards and an adjacent area of native subtropical forest. The means of six replicates.
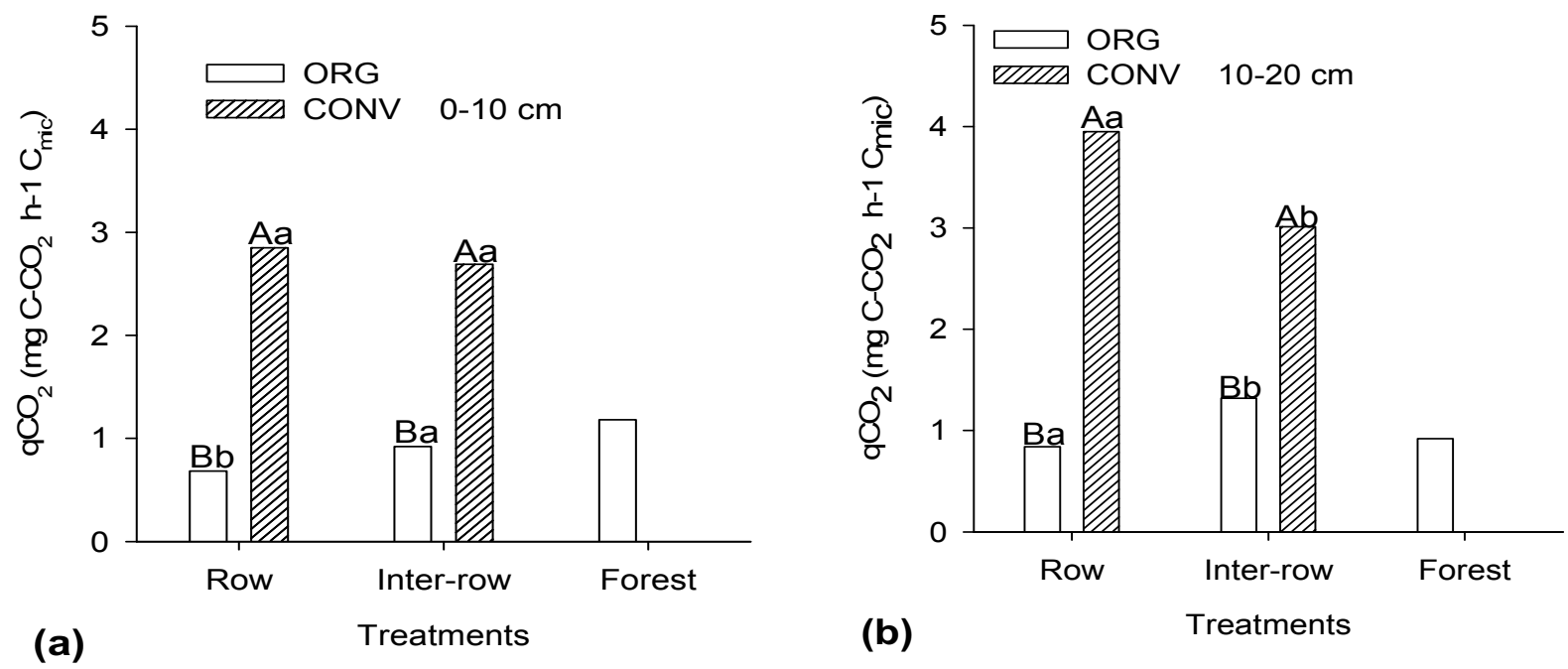

Source: Elaboration of the authors.

Regardless of the sampling depth, the lowest values of $\mathrm{qCO}_{2}$ were observed in the ORG vineyard and the forest. In the $0-10 \mathrm{~cm}$ layer, it was observed by cluster analysis that, when $\mathrm{C}_{\text {mic }}$ values are plotted on the Axis-X, the CONV vineyards, ORG vineyards and forest cluster from the negative to the positive, progressively, indicating greater similarity between ORG and forest. On the Axis-Y, the 0-10 $\mathrm{cm}$ layer appeared in the positive portion, and the $10-20 \mathrm{~cm}$ layer appeared in the negative portion. In the short term, the vineyard management methods affected chemical variables and $\mathrm{C}_{\text {mic }}$ in this Oxisol system.

Permanent vegetation and a large amount of plant biomass and litter in the forest area result in a stable microbial community in this soil, as shown by the higher $\mathrm{C}_{\text {mic }}$ content and lower MBR values observed in our study. Less disturbance and the presence of soil cover (vegetation), which are conditions that existed between rows in the ORG vineyard, may result in lower $\mathrm{qCO}_{2}$ values compared to $\mathrm{CONV}$ management, increasing the $\mathrm{C}_{\text {mic }}$ without reducing the basal respiration (MÄDER et al., 2002). There are reports that the soil microbial metabolism was affected by the use of the some herbicides when applied to genetically modified soybeans, for example.

Vineyard management, soil spatial heterogeneity and forest areas

Discriminant analysis can identify the correlation significance (Person coefficient) between subgroups of treatments (AMARAL et al., 2011b). Exploratory analyses may reveal the existence of clusters or groups of objects in a data set (RAMETTE, 2007).

For the results obtained by both the univariate statistics and discriminant analyses, $\mathrm{C}_{\text {mic }}$ (on the Axis-X) was the most important variable for distinguishing CONV management from the other management methods. On the other hand, for the average values observed for $\mathrm{MBR}$ and $\mathrm{qCO}_{2}$ (microbial activity), the factor sampling depth, vineyard management method, and forest location determined the dissimilarity of the treatments, progressing from positive to negative on the Axis-Y (Figure 2). The vineyard managements and forest 
factors indicated increased microbial activity in soil between CONV rows at depths of 10-20 cm, which could be explained by the stimulation of fertilizers with high water solubility and higher exposure to the soil in these areas, where there may be greater percolation of pesticides.

The discriminant analysis showed that the ORG vineyard or forest area appears in the positive range of the Axis- $\mathrm{X}$ and that the CONV vineyard appears in the negative range. These results may reinforce the positive benefits of organic practices on $\mathrm{C}_{\text {mic }}$ (Figure 2) (AMARAL et al., 2011b). The microbial activity, as determined by $\mathrm{MBR}$ and $\mathrm{qCO}_{2}$, was positive in CONV rows at all depths, between the ORG rows at depths of $0-10 \mathrm{~cm}$, and in the forest soil (Figure 2). The factor "management" indicated increased microbial activity in soil between CONV rows at $10-20 \mathrm{~cm}$, which is justified by the stimulation of fertilizers with high water solubility and higher exposure to the soil in these areas, where there may be greater percolation of pesticides. The soil from the ORG vineyard exhibited an increase in organic matter, mainly due to different sources of organic material, as sugar cane bagasse and manure, and constant maintenance of cover crops between rows in the summer and winter.

Figure 2. Discriminant analysis by PCA for management and spatial heterogeneity of soil in organic (ORG) and conventional (CONV) vineyards and an adjacent native forest.

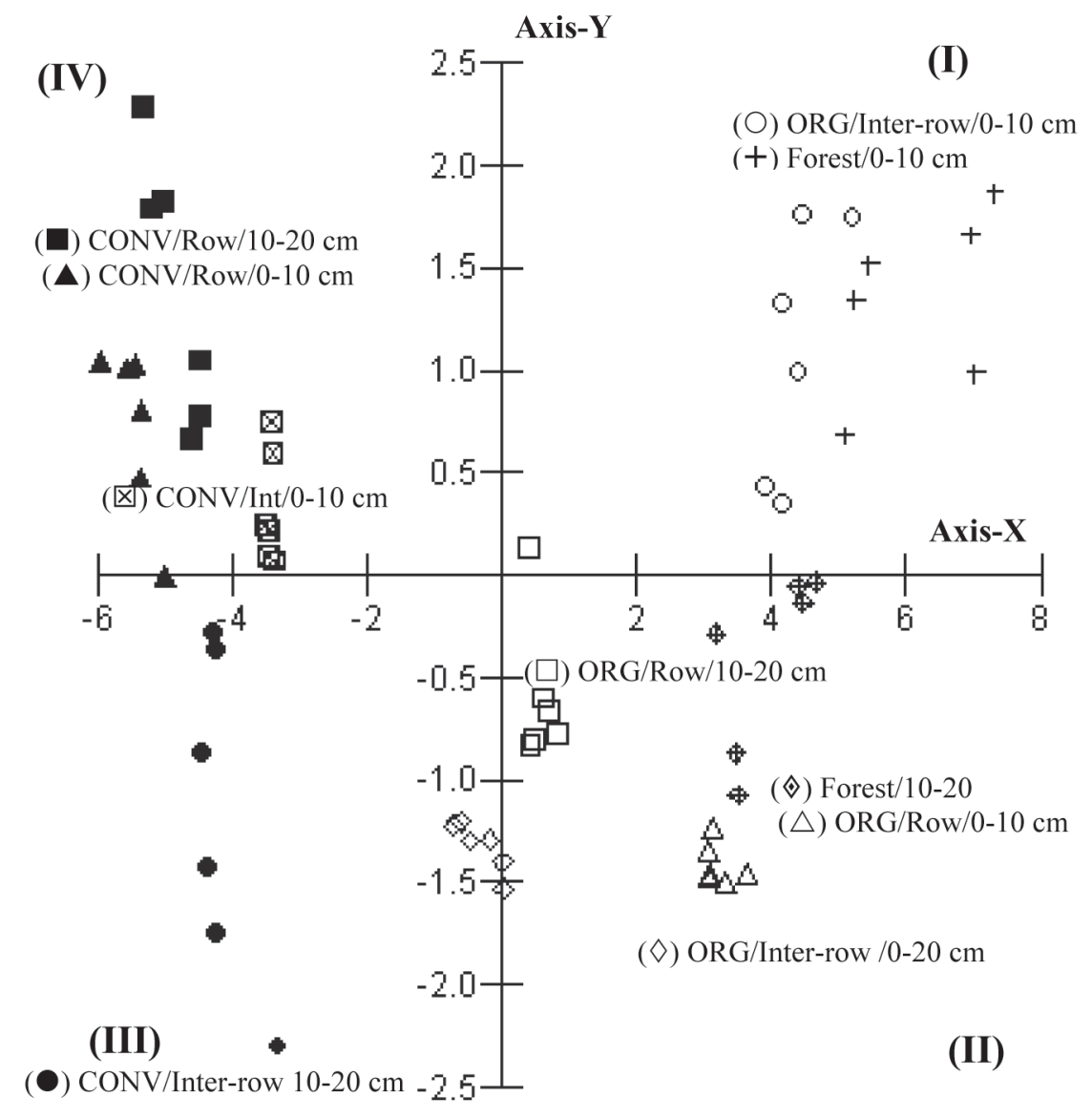

Source: Elaboration of the authors. 


\section{Conclusion}

Some chemical attributes in the soil from the ORG vineyard were improved in comparison to the soil from the forest, at depths of $0-10 \mathrm{~cm}$, with the exception of total carbon.

In the short term, the soil from an organically managed vineyard demonstrated an increase in levels of microbial carbon. In contrast, $\mathrm{C}_{\text {mic }}$ is decreased in a conventionally managed vineyard. Therefore, the management method was the most important factor affecting the levels of $\mathrm{C}_{\text {mic }}$.

There is spatial heterogeneity in soil and microbial characteristics. The microbial activity, measure by MBR and $\mathrm{qCO}_{2}$, in the soils under the organic vineyard at $0-10 \mathrm{~cm}$ depth was similar to the soil under the native forest, showing that this type of vineyard management positively interferes in the recycling of nutrients, throughout carbon mineralization.

\section{Acknowledgements}

H F Amaral is grateful to the National Council for Scientific and Technological Development (CNPq) for the scholarship at the Universidade Estadual de Maringá (UEM), PR, Brazil. This work was supported by the Fundação Araucária (convênio $n^{\circ}$ 023/2003) and Agronomic Institute of Paraná State (IAPAR).

\section{References}

ABREU JUNIOR, H. Práticas alternativas de controle de pragas e doenças na agricultura: coletânea de receitas. Campinas, SP: Editora EMOPI, 1998, 115p.

ALTIERI, M. M. Agroecologia: bases científicas para uma agricultura sustentable. Montevideo-Uruguay: Nordan Comunidad, 1999. 338 p.

AMARAL, H. F.; YADA, I. F. U.; VASCONCELLOS, M. E. C. Aplicações e perspectivas de modelos univariados e multivariados em microbiologia do solo. In: REUNIÃO ANUAL DA REGIÃO BRASILEIRA DA SOCIEDADE INTERNACIONAL DE BIOMETRIA, 56; SIMPÓSIO DE ESTATÍSTICA APLICADA A AGRONOMIA, 14.,
2011, Maringá. Anais... Maringá: UEM, 2011a. CDROM.

AMARAL, H. F.; SENA, J. O. A.; SCHWANESTRADA, K. R. F.; BALOTA, E. L.; ANDRADE, D. S. Soil chemical and microbial properties in vineyards under organic and conventional management in southern Brazil. Revista Brasileira de Ciência do Solo, Viçosa, MG, v. 35, n. 5, p. 1517-1526, 2011 b.

ANDERSON, J. P.; DOMSCH, K. H. A physiological method for the quantitative measurement of microbial biomass in soils. Soil Biology. Biochemistry, Oxford, v. 10, n. 1, p. 215-221, 1978.

ANDRADE, D. S.; MURPHY, P. J.; GILLER, K. E. The diversity of phaseolus-nodulatin rhizobial populations is altered by liming of acid soils planted with plaseolus vulgaris L. in Brazil. Applied and Environmental Microbiology, Washington D.C, v. 68, n. 8, p. 4025-4034, 2002.

ANDRADE, D. S.; COLOZZI-FILHO, A.; GILLER, K. E. The soil microbial community and soil tillage. In: TITI, A. E. (Ed.). Soil tillage in agroecosystem. Boca Raton: CRC Press LLC, 2003, p. 51-81.

ARAÚJO,A.; LEITE,L.F.; SANTOS, V.B.; CARNEIRO, R. F. Soil microbial activity in conventional and organic agricultural systems. Sustainability, Switzerland, v. 1, n. 2, p. 268-276, 2011.

AYRES, M.; AYRES JUNIOR, M.; AYRES, D. L.; SANTOS, A. A. S dos. Bio Estat. Aplicações estatísticas nas áreas das ciências médicas. 5. ed. Belém: Sociedade Civil Mamirauá, 2007. 339 p.

BALOTA, E. L.; COLOZZI-FILHO, A.; ANDRADE, D. S.; DICK, R. P. Microbial biomass in soils under different tillage and crop rotation systems. Biology Fertility of Soils, Berlim, v. 38, n. 1, p. 15-20, 2003.

BALOTA, E. L.; COLOZZI-FILHO, A.; ANDRADE, D. S. O manejo do solo e a atividade microbiana. In: KISHINO, A. Y.; CARVALHO, S. L. C.; ROBERTO, S. R. Viticultura tropical: o sistema de produção do Paraná. Londrina: IAPAR, 2007. cap. 7, p. 213-222.

BETTIOL, W.; TRATCH, R.; GALVÃO, J. A. H. Controle de doenças de plantas com biofertilizantes. Jaguariúna: EMBRAPA/CNPMA, 1997. 22 p. (Circular Técnica, 2).

BOHM, G. M. B.; SCHENEIDER, L.; CASTILHOS, D.; AGOSTINETTO, D.; ROMBALDI, C. V. Controle de plantas daninhas, biomassa e metabolismo microbiano do solo em função da aplicação de glifosato ou imazetapir na cultura da soja. Semina: Ciências Agrárias, Londrina, v. 32, n. 3, p. 919-930, 2011. 
BRASIL. Instrução normativa n. 07, de maio de 1999. Normas de produção, tipificação, processamento, envase, distribuição, identificação e de certificação da qualidade para os produtos orgânicos de origem vegetal e animal. Diário Oficial [da] União, Brasília, DF. de 17 de maio de 1999. p. 11- 14. Seção 1.

BURG, I. C.; MAYER, P. H. Alternativas ecológicas para prevenção e controle de pragas e doenças. Francisco Beltrão, PR. Grafit, 2001, 153 p.

CAVAlCANTE, E. G. S.; ALVES, M. C.; SOUZA, Z. M.; PEREIRA, G. T. Variabilidade espacial de atributos químicos do solo sob diferentes usos e manejos. Revista Brasileira de Ciências do Solo, Viçosa, MG, v. 31, n.1, p. 1329-1339, 2007.

DAL BÓ, M. A. Efeito da adubação NPK na produção, qualidade de uva e nos teores foliares de nutrientes da videira. Revista Brasileira de Fruticultura, Cruz das Almas, v. 14, n. 2, p. 189-194, 1992.

FARIA, C. M. B.; SOARES, J. M.; LEÃO, P. C. S. Adubação verde com leguminosas em videira no submédio São Francisco. Revista Brasileira de Ciência do Solo, Viçosa, MG, v. 28, n. 2, p. 641-648, 2004.

FLIEBACH, A.; OBERHOLEZER, H. R.; GUNST, L.; MÄDER, P. Soil organic matter and biological soil quality indicators after 21 years of organic and conventional farming. Agriculture Ecosystems Environment, Duch, v. 118, n. 1, p. 273-284, 2007.

KISHINO, A. Y. Característica da planta. In: KISHINO, A. Y.; CARVALHO, S. L. C.; ROBERTO, S. R. Viticultura tropical: o sistema de produção do Paraná. Londrina: IAPAR, 2007. cap. 4, p. 87-138.

LIU, B.; GUMPERTZB, M. L.; HUA, S.; RISTAINO, J. B. Long-term effects of organic and synthetic soil fertility amendments on soil microbial communities and the development of southern blight. Soil Biology and Biochemistry, Oxford, v. 39, n. 1, p. 2302-2316, 2007.

MÄDER, P.; FLIESSBACH, A.; DUBOIS, D.; GUNST, L.; FRIED, P.; NIGGLI, U. Soil fertility and biodiversity in organic farming. Science, Savoy, v. 296, n. 2, p. 16941697, 2002.

MATSUOKA, M.; MENDES, I. C.; LOUREIRO, M. F. Biomassa microbiana e atividade enzimática em solos sob vegetação nativa e sistemas agrícolas anuais e perenes na região de Primavera do Leste (MT). Revista Brasileira de Ciências do Solo, Viçosa, MG, v. 27, n. 2, p. 425-433, 2003.

MOTA, I. de S. Maracujazeiro em produção orgânica e convencional: cultivares, qualidade da fruta e análise econômica. 2005. Tese (Doutorado) - Universidade Estadual de Maringá, Maringá.
NDOUR, N. Y. B.; ACHOUAK, W.; CHRISTEN, R.; HEULIN, T.; BRAUMAN, A.; CHOTTE, J. L. Characteristics of microbial habitats in a tropical soil subject to different fallow management. Applied Soil Ecology, Amsterdam, v. 38, n. 2, p. 51-61, 2008.

NELSON, D. W.; SOMMERS, L. E. Total carbon, organic carbon and organic matter. In: PAGE, A. L. et al. (Ed.). Methods of soil analysis part 2. Wis: American Society of Agronomy, 1982. 539 p.

NOGUEIRA, M. A.; ALBINO, U. B.; BRANDAOJUNIOR, O.; BRAUM, G.; CRUZ, M. F.; DIAS, B. A.; DUARTE, R. T. D.; GIOPPO, N. M. R.; MENNA, P.; ORLANDI, J. M.; RAIMAM, M. P.; RAMPAZO, L. G. L.; SANTOS, M. A.; SILVA, M. E. Z.; VIEIRA, F. P.; TOREZAN, J. M. D.; HUNGRIA, M.; ANDRADE, G. Promising indicators for assessment of agroecosystems alteration among natural, reforested and agricultural land use in southern Brazil. Agriculture Ecosystem Environment, Duch, v. 115, n. 3, p. 237-247, 2006.

PAGLIA, E. C. Avaliação transversal de sistemas agroecológicos e convencional de produção de uva na Serra Gaúcha. 2007. Tese (Doutorado em Agronomia) Universidade Federal do Paraná, Curitiba.

PAVAN, M. A.; BLOCH, M. F. M.; ZEMPULSKI, H. C.; MYAZAWA, M.; ZOCOLER, D. C. Manual de análise química de solo e controle de qualidade. Londrina: IAPAR, 1992. 40 p. (Circular, 76).

POWLSON, D. S.; BROOKES, P. C. Measurement of soil microbial biomass provides an early indication of changes in total soil organic matter due to straw incorporation. Soil Biology Biochemistry, Berlim, v. 19, n. 2, p. 159-164, 1987.

RAMETTE, A. Multivariate analyses in microbial ecology. FEMS Microbial Ecology, Federation of European Microbiological Societies, v. 62, n. 1, p. 142160, 2007.

ROMBALDI, C. V.; BERGAMASQUI, M.; LUCCHETTA, L.; ZANUZO, M.; SILVA, J. A. Produtividade e qualidade de uva, cv. Isabel, em dois sistemas de produção. Revista Brasileira de Fruticultura, Cruz das Almas, v. 26, n. 3, p. 89-91, 2004.

SAAB, O. J. G. A.; ANTUNIASSI, U. R.; FONSECA, I. C. B.; GENTA, W.; BATISTELA, M. Efeito do tamanho de gota e volume de aplicação na deposição de agrotóxicos em folhas de videira. Semina: Ciências Agrárias, Londrina, v. 23, n. 2, p. 221-228, 2002.

SAMPAIO, B. D.; SANTOS, V. B.; ARAÚJO, A. S. F. Doses de paclobutrazol sobre a biomassa microbiana do solo. Semina: Ciências Agrárias, Londrina, v. 31, p. 1349-1354, 2010. Suplemento 1. 
SAS Institute. SAS/STAT. User's guide. Release 6. 12. ed. Cary, N. C, USA. SAS Institute Inc, 1998.

SCHERER, A. Agregação e biomassa microbiana do solo em diferentes sistemas de cultivo de cafeeiros. 2005. Dissertação (Mestrado em Agronomia) - Universidade Estadual de Londrina, Londrina.

SOIL SURVEY STAFF. Soil taxonomy. A basic system of soil classification for making and interpreting soil surveys. Washington, USDA/NRCS DC, 1999.

SPARLING, G. P. Soil microbial biomass, activity and nutrient cycling as indicators of soil health. In: PANKHURST, C. E.; DOUBE, B. M.; GUPTA, V. V. S. R. Biological indicators of soil health. Wallingford: $\mathrm{CAB}$ International, 1997. cap. 5, p. 97-119.

SPARLING, G. P.; WEST, A. W. A direct extraction method to estimate soil microbial C: calibration in situ using microbial respiration and ${ }^{14} \mathrm{C}$ labeled cells. Soil Biology Biochemistry, Berlim, v. 2, n. 20, p. 337-343, 1988.

VAN RAIJI, B.; CANTARELLA, H.; QUAGGIO, J. A.; FURLANI, A. M. C. Recomendações de adubação e calagem para o Estado de São Paulo. Campinas: Instituto Agronômico/Fundação IAC, 1997. 285 p. (Boletim técnico, 100).
VANCE, E. D.; BROOKES, P. C.; JENKINSON, D. S. An extraction method for measuring soil microbial biomass C. Soil Biology Biochemistry, Berlim, v. 19, n. 3, p. 703-707, 1987.

WARDLE, D. A.; GHANI, A. A critique of the microbial metabolic quotient $\left(\mathrm{qCO}_{2}\right)$ as a bioindicator of disturbance and ecosystem development. Soil Biology Biochemistry, Berlim, v. 27, n. 1, p. 1601-1610, 1995.

WUTKE, E. B.; TERRA, M. M.; PIRES, E. J. P.; COSTA, F.; SECCO, I. L.; RIBEIRO, I. J. A. Influência da cobertura vegetal do solo na qualidade de frutos de videira 'Niágara rosada'. Revista Brasileira de Fruticultura, Cruz das Almas, v. 27, n. 1, p. 434-439, 2005.

WUTKE, E. B.; CARVALHO, C. R. L.; COSTA, F.; TERRA, M. M.; PIRES, E. J. P.; SECCO, I. L.; RIBEIRO, I. J. A. Qualidade de frutos de videira 'niagara rosada' em cultivo intercalar com graminea e leguminosa. Revista Brasileira de Fruticultura, Cruz das Almas, v. 26, n. 1, p. 92-96, 2004.

XAVIER, F. A. S.; MAIA, S. M. F.; OLIVEIRA, T. S.; MENDONÇA, E. de S. Biomassa microbiana e matéria orgânica leve em solos sob sistemas agrícolas orgânico e convencional na Chapada da Ibiapaba - CE. Revista Brasileira de Ciências Solo, Viçosa, v. 30, n. 3, p. 247258, 2006. 